\title{
LA NECIA HISTORIA
}

Julián Meza*

Para dar razón a Karl Marx, una y otra vez la historia se repite, pero ahora siempre como farsa. Cuenta Imre Kertész que el gran poeta húngaro Miklós Radnóti (judío convertido al catolicismo por 'razones estéticas' y convicción) fue siempre un gran patriota. Tras años de trabajos forzados fue fusilado y enterrado en una fosa común. Exhumada la fosa se encontró el cadáver del poeta, que en uno de los bolsillos de su abrigo llevaba una libreta de apuntes. Para dar forma poética a su amor a la patria húngara eligió, escribe Kertész, una original perspectiva:

(...) la del piloto del bombardero enemigo -es decir, angloamericano- quien desde las alturas escruta como mero territorio y objetivo el paisaje que para el poeta significa algo muy diferente: la casa natal, la tierra de aquí abajo poblada por caminos entrañables, los recuerdos de infancia, las amistades, la mujer amada... ${ }^{1}$

Entregado por las autoridades húngaras a los nazis, Radnóti nunca dejó de ser el judío húngaro convertido al catolicismo por 'razones estéticas'. En pocas palabras: era un auténtico patriota húngaro. La palabra patria es hoy, sin embargo (advierte líneas atrás Kertész, y con mucha razón), una palabra que da miedo, debido a las malas costumbres, y hoy las malas costumbres son la norma.

* Departamento Académico de Estudios Generales, ITAM.

${ }^{1}$ Imre Kertész, Un instante de silencio en el paredón, 1999, Barcelona, Herder, p.17. 


\section{JULIÁN MEZA}

Para Radnóti el piloto anglo-americano del bombardero veía el paisaje como mero territorio y objetivo, mientras que para el poeta era su patria, magistralmente definida como casa natal, tierra de caminos entrañables, recuerdos de infancia, amistades, mujer amada.

Pese al mal trato de sus propias autoridades, pese a los trabajos forzados que realizó vigilado por sus verdugos alemanes y húngaros, Radnóti nunca dejó de ser un patriota húngaro.

Totalmente ajeno a la poesía, el piloto anglo-americano sólo medía el territorio y buscaba el lugar para arrojar sus bombas sobre un objetivo estratégico que, sin lugar a dudas fue una escuela, un hospital, un refugio para huérfanos o una vivienda, y así producir sólo inevitables daños colaterales. Antes, tal vez se concedía momentos para el recuerdo y evocaba a la novia pecosa en Ohio, la granja de sus padres y la fuente de sodas en donde devoraba hamburguesas y bebía refrescos de cola, pero el recuerdo no lo llevaba a pensar que en el territorio en donde buscaba sus objetivos también había novias pecosas, granjeros locales y personas que comían decentemente. Él sólo largaría las bombas y volvería a su base con la conciencia tranquila porque únicamente habría obedecido órdenes.

82 Algo parecido e igualmente desastroso ocurrió en Vietnam cuando el hijo o el nieto del piloto anglo-americano arrojó bombas de napalm sobre los civiles, pero el poeta vietnamita que escribió sobre su patria murió calcinado, y junto con él sus poemas, creo yo.

Las bombas arrojadas sobre Irak durante la guerra del golfo deben haber borrado del mapa a más de un poeta, cuyo patriotismo siempre será ignorado porque nunca lo leeremos.

Hoy, los patriotas norteamericanos e ingleses se Preparan para borrar del mapa paisajes, hogares, infancias y amores con bombas inteligentes y aviones invisibles porque Cristo es dios y Bush es su profeta, aunque en realidad dios le importa a Bush un comino porque lo único que le interesa es el petróleo iraquí, que está decidido a conquistar para hacerle la guerra a todo el mundo, empezando por Europa, de lo cual no se dan cuenta perfectos idiotas como Aznar y Berlusconi. 
¿Qué es, entonces, la patria para el presidente texano? Obviamente, el petróleo, sus amoríos con el chapopote aznariano, su potencia militar, su luna de miel con el procónsul Blair, su sociedad con mafiosos italianos. En su patria no existen la casa natal, los recuerdos entrañables, la infancia, las amistades, los amores, sino las bombas y los bombarderos. ¿Por qué no abandona la abstinencia y vuelve al recto camino del alcoholismo por el que transitó? Ningún borracho come lumbre. En cambio, este imbécil abstinente cree ser tragafuegos. ¡Que le obsequien unos galones de bourbon! ¡Que se embriague y deje vivir! Quizá entonces tenga tiempo para leer la poesía de Radnóti, aunque seguramente no la entenderá. 
